\title{
Impact of Papaya (Carica papaya L.) on Breast Milk Production Enhancement of Nursing Mothers at Teling Atas Public Health Center, Wanea Subdistrict, Manado City
}

Ellen Pesak ${ }^{1 *}$, Fredrika N Losu ${ }^{1}$, Robin Dompas ${ }^{1}$, Freike Lumy ${ }^{1}$, Gusti Ayu Tirtawati ${ }^{1}$, Dian Pratiwi1, Kusmiyati Kusmiyati ${ }^{1}$, Fiani A Djojobo ${ }^{1}$, Atik Purwandari ${ }^{1}$, Bongakaraeng Bongakaraeng ${ }^{2}$, Nonce Nova Legi ${ }^{3}$, Rivolta Walalangi ${ }^{3}$, Esther N Tamunu ${ }^{4}$, Jon Welliam Tangka ${ }^{4}$

${ }^{1}$ Department of Midwifery, Poltekkes Kemenkes Manado, City of Manado, Indonesia; ${ }^{2}$ Department of Environmental Health, Poltekkes Kemenkes Manado, City of Manado, Indonesia; ${ }^{3}$ Department of Nutrition, Poltekkes Kemenkes Manado, City of Manado, Indonesia; ${ }^{4}$ Department Nursing, Poltekkes Kemenkes Manado, City of Manado, Indonesia

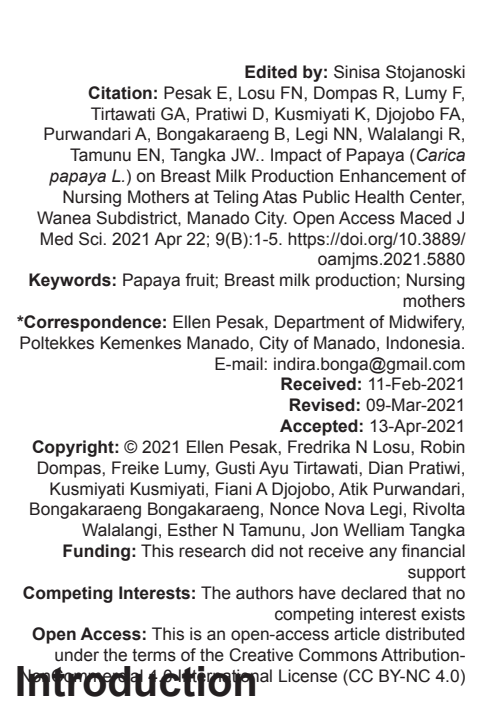

Postpartum is a natural process experienced by women after childbirth that lasts about 6 weeks. There are physiological changes during this period, mainly physical changes, uterine involution and discharge of lochea, psychological changes, and lactation/release of breast milk (ASI). Lactation is when there is a change in the mother's breast to produce breast milk. It is a very complex interaction between mechanical stimuli, nerves, and various hormones so that milk can be released [1].

Breastfeeding is crucial for optimal growth and development, physical and mental, and the baby's intelligence [2]. Exclusive breastfeeding needs special attention from mothers, families, communities, and health workers so that the breastfeeding process can be carried out properly. Balanced nutrition during breastfeeding is important for breastfeeding mothers because it affects breast milk production. Adequacy of nutrition will have an effect on the quality and quantity of breast milk. Proper feeding of babies is to breastfeed the baby exclusively from birth until the age of 6 months. The baby gets nutritious complementary food according to their growth and development needs [3].

The World Health Organization and several countries recommend giving exclusive breastfeeding to babies for the first 6 months after birth and continuing until they are 2 years old [4]. The coverage of exclusive breastfeeding in Indonesia is $61.33 \%$, and this coverage has not reached the national target of $80 \%$. Five provinces have not achieved the 2017 Strategic Plan target, namely, $44 \%$, North Sulawesi, which only got $43.78 \%$ [5].

Various factors influence breast milk production. One of the most influential factors is hormonal factors, namely, the hormone prolactin and the hormone oxytocin [6]. Hormone prolactin affects milk production, while oxytocin affects breast milk production. Prolactin is related to the mother's nutritional 
intake during breastfeeding. The better the nutritional intake, the greater the amount of milk produced [7]. The hormone oxytocin is related to stimulation or touch. The baby sucks the baby's nipple, and it will facilitate expelling breast milk [8]. Another factor that affects the smoothness of breastfeeding is the body's balance factor. Therefore, for breastfeeding to remain smooth, you must continue to carry out sports activities to maintain the body's balance [9].

Papaya is a plant from the Caricaceae family that originates from Central America and is grown in tropical and subtropical areas. This fruit is a fruit that has high nutrition [10]. Papaya is a fruit that contains galactagogue, a substance that can help increase and improve breast milk production. Lactagogue affects stimulating the release of the hormones oxytocin and prolactin, such as alkaloids, polyphenols, steroids, and flavonoids, effectively enhancing the secretion and excretion of breast milk [11]. Papaya fruit is a fruit that contains Lactagogum, which is a drug that can increase and accelerate breast milk production, so this method is one of the non-pharmacological therapies to increase breast milk production [12]. A study showed that the average milk production before consuming papaya was 5.7 times with a standard deviation of 0.8131 and the average after consuming papaya was 9.75 times with a standard deviation of 0.78640 with $p<0.05$ [13].

This study aimed to determine the effect of giving papaya fruit to nursing mothers on breast milk production.

\section{Methods}

The method used in this research was preexperimental using one group pre-test-post-test design. The study population was all breastfeeding mothers whose babies were aged 0-6 months per June 2019, at Teling Atas Public Health Center, Wanea Subdistrict, Manado City. The number of respondents who met the requirements, namely, 30 respondents who were willing to attend the research location, was 14 respondents, who did not continue with 16 respondents. The research sample was determined by purposive sampling method with a sample size of 14 . Inclusion criteria, namely: (1) Breastfeeding mothers are not in a high-risk condition, (high blood pressure, heart disease, diabetes, history of labor by action, and those who experience postpartum infection), (2) breastfeeding mothers with children aged 0-6 months, (3) breastfeeding mothers of reproductive age (20-35 years), (4) breastfeeding mothers with a gestation interval of 2 years, and (5) breastfeeding mothers do not have a history of breast cancer. Exclusion criteria, namely: (1) Respondents who were not present during the study and (2) respondents who are not willing to take part in the research.
The data collection technique used an observation sheet containing the Guttman scale. Observation sheet to find out in full detail the respondents really obey, obey the discipline of consuming papaya fruit for 7 days or for 1 week. The contents of the observation sheet are the identity of the respondent, the amount of papaya consumed, and the number of times a day the papaya is consumed, and the day/date, the hour, and the score/amount of breastfeeding.

Every day is monitored and checked on the observation sheet, every time the respondent consumes papaya fruit, which is 200 grams 3 times a day in a row for 1 week ( 7 days), written the day of the day and time of consuming papaya, including also observing the general condition (blood pressure, pulse, body temperature and respiration) respondent / breastfeeding mother. Researchers are also with the help of Enumerators (Research assistants in the field).

In 1 day, it is given 3 times with a size of $200 \mathrm{~g}$ and given for 7 consecutive days or for 1 week, namely, with the time interval morning at 08.00 , afternoon at 13.00 , and night at 19.00 , then every time papaya fruit is given, it is recorded on the observation sheet including controlling general guidelines of respondents (blood pressure, pulse, body temperature, and respiration) and it is also necessary to write down if there are complaints on the observation sheet after 7 days, controlling the expenditure of breast milk production by communicating with the respondent (breastfeeding mothers) while observing the condition of the mother's nipples and the baby's condition whether the baby still cries a lot, is restless, the baby is gaining or decreasing weight, pooping, and urinating are all written in the observation sheet.

All respondents have agreed to be respondents in this study and a detailed explanation of the aims and objectives of the study, then were clearly told how to consume papaya until the respondent was also taught to check the observation sheet correctly and accurately.

The data analysis was univariate and bivariate analysis using the SPSS application. Data analysis is the Wilcoxon Test. The ethical clearance Number 421/ KEPK/VIII/2019 by Health Research Ethics Committee Poltekkes Kemenkes Manado.

\section{Results}

Table 1 shows that most respondents were less breastfeeding before consuming papaya, about $71.43 \%$. The rest respondents, approximately $28.75 \%$ were in the category of adequate breastfeeding. Meanwhile, most respondents after the intervention were categorized as high breast milk production (12 respondents). The remaining two respondents in the category of sufficient breast milk production. 
Table 2: Comparison of the average level of milk production in breastfeeding mothers after papaya fruit intervention at Teling Atas Community Health Center, Manado City

\begin{tabular}{lllll}
\hline Variables (Breast milk production) & $\mathrm{n}$ & Mean & Std. Dev & $\mathrm{p}<0.05$ \\
\hline Pre-test & 14 & 2.21 & 0.802 & 0.001 \\
Post-test & 14 & 6.36 & 0.745 & \\
\hline
\end{tabular}

Table 1: Distribution of breast milk production before and after the intervention

\begin{tabular}{lllll}
\hline Breast milk production score & \multicolumn{3}{l}{ Before } & After \\
\cline { 2 - 5 } & $\mathrm{n}$ & $\%$ & $\mathrm{n}$ & $\%$ \\
\hline$<3$ (Low) & 10 & 71.43 & 0 & 0 \\
$4-5$ (Adequate) & 4 & 28.57 & 2 & 13 \\
$>6$ (High) & 0 & 0 & 12 & 87 \\
Total & 14 & 100 & 14 & 100 \\
\hline
\end{tabular}

Based on the bivariate analysis results, papaya (Carica papaya L.) affected the increase in breast milk production in breastfeeding mothers at Teling Atas Community Health Center, Manado City using the t-test is shown in Table 2.

Table 2 shows that nursing mothers before and after being given papaya for 7 days increased by 4.1 . The mean value before the intervention was 2.21 , and the standard deviation was 0.802 . After the intervention, the level of milk production increase to 6.36 with standard deviation of 0.745 . Obtained a significance value less than $5 \%$, namely, $p<\alpha=0.000<0.05$, which means that there was a significant difference in the level of milk production before and after consuming papaya fruit.

\section{Discussion}

In this case, the respondents' characteristics were breastfeeding mothers whose babies were 0-6 months old at the Teling Atas Community Health Center in Manado City. Respondents in the study had different ages and parity, with the largest age category being 22 years old at $43 \%$. Most of the respondents were multiparous parity (79\%). Age is an essential variable in the human lifecycle. It is known that the best age for healthy reproduction is the age of 20-35 years. It is considered the golden period for production at this age because the reproductive organs' functions are considered to be ready for pregnancy, childbirth, and breastfeeding.

This study only had one control group initiated by conducting a pre-test, namely, measuring milk production level before the intervention. Next, the papaya fruit was given $200 \mathrm{~g}$ with a frequency of 3 times in 1 day, which was offered for 7 days. After completing the intervention, a post-test was carried out to determine the milk production level after the intervention. This study indicated that the level of milk production before the intervention of 14 breastfeeding mother respondents was included in low breastfeeding, was about $71.43 \%$ or 10 of 14 respondents. The remaining $28.57 \%$ or four respondents were adequately breastfed. The average value of milk production before the intervention was 2.21 and a standard deviation of 0.802 .

Meanwhile, most respondents found an increase in breast milk production after the intervention and categorized high, about 12 of the 14 respondents. The remaining two respondents were in the category of adequate breastfeeding with an average production of 6.36 and a standard deviation of 0.745 . The difference in increased milk production before and after the intervention was 4.15. Increase breast milk (volume, color) is indicated, namely: (1) Babies can sleep well, not crying and restless; (2) consistency of defecating and urinating smoothly every day; (3) baby weight gain increases every week/month; (4) the condition of the mother's nipple protrudes out; (5) mother's nipples have no signs of inflammation such as blisters, redness; and (6) breastfeeding mothers have no complaints when breastfeeding.

Based on the bivariate test results using the t-test on 14 samples, the significance value of $\rho<5 \%$, namely, $\rho<\alpha=0.001<0.05$. It means that there was a very significant difference in milk production level before and after giving papaya. This result shows that giving papaya fruit affects increasing breast milk production so that papaya fruit can be used as an alternative to increasing breast milk production. The production of breast milk can increase or decrease depending on the stimulation of the breast glands. In contrast, one of the factors that can affect milk production is the mother's nutritional status. Suppose the mother's food continuously does not meet adequate dietary intake, of course. In that case, the milkproducing glands in the mother's breast will not work properly. They will ultimately affect milk production [14].

Papaya fruit is a type of plant containing galactagogues that can stimulate the hormones oxytocin and prolactin, such as alkaloids, polyphenols, steroids, flavonoids, and other substances that are most effective in increasing and accelerating breast milk production [15]. Hormonal prolactin reflex to produce breast milk when the baby sucks the mother's nipple, neurohormonal stimulation occurs in the nipple and areola. The lagtagogum mechanism in helping to increase the rate of secretion and milk production is by directly stimulating protoplasmic activity in the secretory cells of the mammary glands which results in increased milk secretion or stimulates the hormone prolactin which is a lactagonic hormone against mammary in the Alveolar Epithelium cells which will stimulate lactation.

Papaya has gastroprotective, antibacterial, laxative, and lactonic effects whose properties have been scientifically proven from papaya fruit [16]. The galactagogue content in papaya can be one way to increase the secretion and production of breast milk and be a strategy to overcome the failure of exclusive breastfeeding caused by low breast production milk [17]. The previous research shows that papaya fruit giving can influence mothers' breastfeeding production, with $\rho=<0.05$ [13]. Other studies show that the average milk production before consuming papaya fruit is 5.05 . After 
consuming papaya, the average increases to 8.20 . The correlation between the two variables was 0.005 . There is a significant difference in the increase in breast milk production between the intervention group and the control group of 3.15 and $p$ value $<0.05$. It shows an increase in breastfeeding mothers' milk production given papaya fruit for 7 consecutive days [18]. This research is supported by the research of Istiqomah et al. (2014) on the effect of giving young papaya fruit on the smooth production of breast milk in breastfeeding mothers, namely, the Paired t-test, the value of $p=0.0005(p<0.05)$ means that there is an effect of giving papaya on the smooth production of breast milk [19] and the average diameter of lactating mamma kelenjar in the water extract group of papaya fruit was greater than the negative control group [20].

The limitations of this study are the number of respondents who are still lacking, the control of food intake is not controlled enough and the research time is limited, so the researchers suggest to the next researchers that the number of respondents and the food intake of each respondent are monitored and controlled.

\section{Conclusion}

The milk production level in breastfeeding mothers at the Teling Atas Community Health Center in Manado City before the intervention on average had less milk production, about 10 of 14 nursing mothers $(71.43 \%)$. In comparison, the remaining four nursing mothers (28.57\%) had sufficient milk production. After the intervention was carried out, an average of 12 of 14 breastfeeding mothers $(87 \%)$ had adequate milk production. The remaining two breastfeeding mothers $(13 \%)$ had sufficient milk production. Papaya fruit was effective in increasing breast milk production in nursing mothers.

\section{Acknowledgment}

The author would like to thank the Teling Atas Community Health Center, Wanea Subdistrict, Manado City, for giving permission and support in implementing this research data collection.

\section{References}

1. Pillay J, Davis TJ. Physiology, lactation. In: Stat Pearls. Treasure Island, FL: Stat Pearls Publishing; 2020.

2. Dimitrovska-Ivanova M, Zisovska E. Impact of Breast Milk Secretory Immunoglobulin A on Infants Acute Gastroenteritis. Open Access Maced J Med Sci. 2020 Aug 30; 8(B):897-901. https://doi.org/10.3889/oamjms.2020.5259

3. Prell C, Koletzko B. Breastfeeding and complementary feeding. Dtsch Arztebl Int. 2016;113(25):435-44.

PMid:27397020

4. World Health Organization, Infant and Young Child Feeding; 2020 Available from: https://www.who.int/news-room/fact-sheets/detail/ infant-and-young-child-feeding. [Last accessed on 2021 Feb 07].

5. Kementerian Kesehatan RI, Profil Kesehatan Republik Indonesia Tahun 2017; 2018.

6. Machmudah M, Khayati N, Widodo S, Hapsari ED, Haryanti F. Improvement of prolactin hormone levels on postpartum mothers taken by the Oketani massage and pressure in GB-21 point. Indones J Nurs Pract. 2020;4(1):1-6. https://doi.org/10.18196/ ijnp.41101

7. Pangestuti DR. Nutritional status of exclusive compared to non exclusive breastfeeding mother. Jgizipangan. 2018;13(1):11-6. https://doi.org/10.25182/jgp.2018.13.1.11-16

8. Widström AM, Brimdyr K, Svensson K, Cadwell K, Nissen E. Skinto-skin contact the first hour after birth, underlying implications and clinical practice. Acta Paediatr. 2019;108(7):1192-204. https://doi.org/10.1111/apa.14754

9. National Research Council (US) Subcommittee on Nutrition and Diarrheal Diseases Control; National Research Council (US) Subcommittee on Diet, Physical Activity, and Pregnancy Outcome. Impact of Physical Activity and Diet on Lactation. Washington, DC: National Academies Press; 1992. https://doi. org/10.2172/771259

10. Pinnamaneni R. Nutritional and medicinal value of papaya (Carica papaya Linn.). World J Pharm Pharm Sci. 2017;6(8):2559-78. https://doi.org/10.20959/wjpps20178-9947

11. Murtiana T. Buah Pepaya. Jakarta: Pustaka Cipta; 2011.

12. Nataria D, Oktiarini S. Increased production of breast milk with the papaya fruit consumption. J Kesehat. 2019;9(1):1. https:// doi.org/10.35730/jk.v9i1.340

13. Muhartono M, Graharti R, Gumandang HP. The effect of papaya (Carica papaya L.) towards breast milk production in breastfeeding mothers. Medula. 2018;8:39-43. https://doi. org/10.14710/jnc.v1i1.427

14. Bravi F, Wiens F, Decarli A, Dal Pont A, Agostoni C, Ferraron M. Impact of maternal nutrition on breast-milk composition: A systematic review. Am J Clin Nutr. 2016;104(3):646-62. https:// doi.org/10.3945/ajcn.115.120881 PMid:27534637

15. Nataria D, Oktiarini $S$. Increase in breast milk production by consuming papaya fruit. J Kesehatan Prima Nusantara Bukittinggi. 2018;9(1):7-10.

16. Herlinda LA. Description of the successful production of post pubily ASI by consuming pepaya fruit in BPM Bengkulu City. In: Proceeding the 4th International Conference On Health Science (ICH), Bengkulu; 2020. p. 99-104.

17. Syarief $H$, Damanik RM, Sinaga $T$, Doloksaribu $T H$ Utilizationand Product Development of Bangun-bangun Leaves as Supplement and Functional Food for Lactating Mother. J IImu Pertanian Indones. 2014;19(1):38-42.

18. Kurniati D, Mardiyanti S, Suprihatin DS. Differences in breastmilk production in the provision of processed papaya fruit to postpartum mothers at BPM Maria Kota Bandar Lampung in 2018. J IImiah Kesehatan Kebidanan. 2018;7(2):1-8.

19. Istiqomah WA. The effect of papaya fruit on the smooth production of breastmilk in breastfeeding mothers in Wonokerto Village, Peterongan Community Health Center, Jombang in 2014. Eduhealth. 2015;5(2):102-8.

20. Kharisma Y, Ariyoga A, Sastramihardja HS. Effect of Unripe Papaya (Carica papaya L.) Aqueous Extract on Histological Feature of Mice Lactating Mammary Glands. MKB. 2011;43(4):160-5. https://doi.org/10.15395/mkb.v43n4.63 